\title{
Plasmids of Pseudomomas aeruginosa Bacteria Isolated from Various Human Infections
}

\author{
Khalid D. Ahmad \\ Department of Biology \\ College of Education \\ Mosul University
}

\author{
Adel K. Khader \\ Department of Biology \\ College of Education \\ Salah-Edin University
}

(Received 1/ 11 / 2009 ; Accepted 28 / 12/ 2009)

\begin{abstract}
The isolated bacteria of Pseudomonas aeruginosa from patients suffering from various infections in Erbil city hospitals were identified depending on the basis of morphological, cultural characters and biochemical tests. Genetic transformation of the laboratory Escherichia coli K-12 (JM83 strain) by the plasmids isolated from P. aeruginosa bacteria showed that the genes encoding resistance to ampicillin, cefotaxime, erythromycin, gentamycin , nalidixic acid, rifampicin, tetracycline, trimethoprim, mercury chloride and the gelatinase enzyme production are located on plasmid DNA molecules, but genes coding for lincomycin resistance and pyocyanin production are on chromosomal DNA of these bacteria. The results obtained were supported by gel electrophoresis and plasmid curing experiments.
\end{abstract}

\section{بلازميدات جرالثي

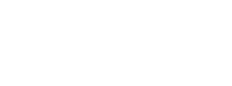

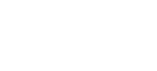

جرالثيم P. aeruginosa

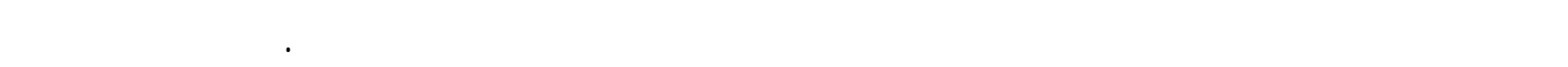

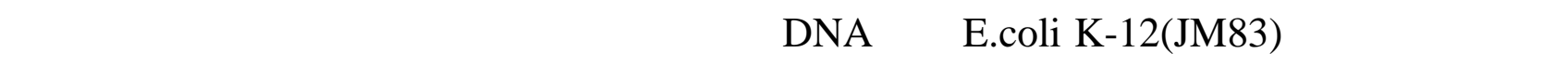

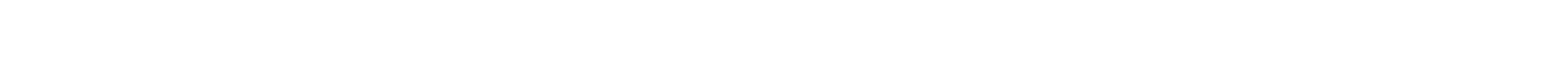

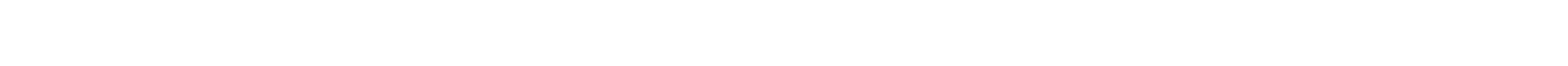
جزيئت ل مNA البلازميدي للبكتريا. بينما الجين المشفر المقاومة المضاد الحيوي لنكومليسين وتلكئك

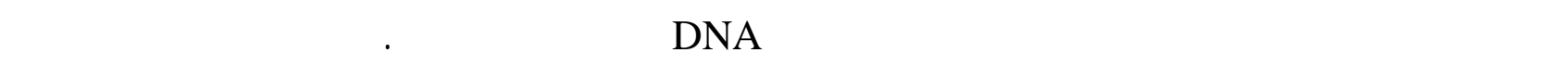
عليها دعمت بتجارب الترحل الكهربائي والتحييد البلازميدي. 